JFFI. 2019; 6(2) 353-359

www.jurnal.farmasi.umi.ac.id/index.php/fitofarmakaindonesia

\title{
AKTIVITAS ANTIJAMUR EKSTRAK ETANOL DAUN KESUM (Polygonum minus Huds.) TERHADAP Microsporum canis
}

\author{
Vica Vionita Rosalim¹, Syarifah Nurul Yanti Rizki Syahab Asseggaf², Diana Natalia ${ }^{3 *}$, \\ Mahyarudin ${ }^{4}$ \\ ${ }^{1}$ Prodi Kedokteran, Fakultas Kedokteran, Universitas Tanjungpura \\ ${ }^{2}$ Departemen Farmakologi, Fakultas Kedokteran, Universitas Tanjungpura \\ ${ }^{3}$ Departemen Parasitologi, Fakultas Kedokteran, Universitas Tanjungpura \\ ${ }^{4}$ Departemen Mikrobiologi, Fakultas Kedokteran, Universitas Tanjungpura \\ *diananatalia@medical.untan.ac.id
}

Submission Date: 13-02-2019; $\quad$ Review Completed: 02-08-2019; $\quad$ Accepted Date: 02-08-2019

\begin{abstract}
Dermatophytosis is a fungal infection caused by one of the superfixial mycoses, namely dermatophytes. Microsporum canis is one of the dermatophyte species that can infect hair, skin, leg and thighs. Kesum plants (Polygonum minus Huds.) are endemic plants of West Kalimantan that have many bioactive compounds from the roots to the leaves. The leaves of kesum contain secondary metabolites which can inhibit fungi growth. This research had purpose to know the antifungal activity of kesum leaves' ethanol extracts on Microsporum canis. The kesum leaves' extraction used maceration method with $96 \%$ ethanol as a solvent. Analysis secondary matbolites of kesum leaves' secondary metabolites used tube test and thin layer chromatography. Antifungal activity test used Kirby-Bauer disk diffusion method with 5 extract concentration variantions i.e. 80, 40\%, 20\%, 10\%, and 5\%. Itraconazole $8 \mu \mathrm{g} /$ disk was used as a positive control and DMSO 10\% was used as a negative control. Kesum leaves' ethanol extract was obtained saponin, flavonoid, alkaloid, therpenoid, and phenol. Ethanol extracts of kesum leaves did not create zone of inhibition against Microsporum canis. Ethanol extracts of kesum leaves didn't have antifungal activity against Microsporum canis.
\end{abstract}

Keywords: Kesum; antifungal; Microsporum canis

\section{PENDAHULUAN}

Lebih dari $20-25 \%$ populasi dunia mengalami mikosis superfisial. Mikosis superfisial adalah penyakit jamur di lapisan permukaan kulit (stratum korneum, rambut dan kuku). Mikosis superfisial yang paling dominan terjadi adalah dermatofitosis, yaitu infeksi jamur yang disebabkan oleh jamur golongan dermatofita (Sutanto et al, 2008; Vena et al, 2012; Widaty dan Budimulja, 2016). Insiden dermatofitosis di Indonesia cukup banyak, yaitu sebesar 52\% dari seluruh dermatomikosis (Sutanto et al, 2008; Yossela, 2015). Hal ini didukung oleh suhu dan kelembapan Indonesia yang tinggi (Sutanto et al, 2008; Kanti dan Rahmanisa, 2014). Data dari Unit Penyakit Kulit dan Kelamin RS. dr. Cipto Mangunkusumo mencatat bahwa dermatofitosis menempati peringkat 1 dalam kasus mikosis superfisial (Bertus et al, 2014).

Satu di antara penyebab dermatofitosis adalah Microsporum canis (Sutanto et al, 2008). Microsporum canis merupakan dermatofita zoofilik yaitu, spesies dermatofit yang berasal dari hewan terutama kucing dan anjing (Widaty dan Budimulja, 2016). Microsporum canis memiliki cara penyebaran yang beragam yaitu melalui hewan, manusia, penggunaan barang pribadi bersama (Sutanto et al, 2008; Kanti dan Rahmanisa, 2014). Data Poliklinik Ilmu Kesehatan Kulit dan Kelamin (IKKK) RSUPN dr. Cipto Mangunkusumo (RSCM) Jakarta pada tahun 2005 sampai 2010 menyatakan terdapat 23 kasus tinea kapitis yang mana sebanyak 56,525 sampel berhasil dikultur dan ditemukan spesies $M$. canis sebanyak 69,23\% (Sari et al, 2012).

Kematian yang disebabkan infeksi dermatofitosis jarang terjadi namun yang menjadi masalah adalah menurunnya kualitas hidup pasien (Sutanto et al, 2008; Siregar, 2014). Penanganan dermatofitosis adalah dengan memperbaiki pola hidup bersih dan sehat serta terapi medikamentosa berupa obat antifungi. Namun perlu kita ketahui bahwa beberapa obat antifungi memiliki efek toksik 
serta jamur mulai mengalami resistensi terhadap obat (Katzung, 2015).

Kekayaan alam Indonesia yang telah lama digunakan sebagai obat oleh masyarakat yaitu tanaman kesum (Polygonum minus Huds), yang merupakan salah satu tanaman endemik Kalimantan Barat (Fitriana et al, 2014). Daun kesum telah dikenal sebagai obat tradisional, penyedap masakan, dan bahan parfum. Selain itu adanya efek sebagai antioksidan, antibakteri, antifungal, antiulserasi, memperbaiki kerusakan paru, dan pencegah efek samping obat kemoterapi juga telah diteliti (Syaiful et al, 2015; Imelda, 2013; Michael et al, 2013; Wibowo et al, 2013). Kemudian studi mengenai famili Polygonaceae yaitu Polygonum aviculareae (akar) dan Polygonum equistiforme (bagian atas) sebagai antijamur pada Microsporum canis dan Trichophyton rubrum menunjukkan bahwa dua tanaman tersebut memiliki aktivitas antijamur terhadap kedua jamur uji (Maoz dan Neeman, 1998).

Polygonum minus Huds. mengandung senyawa golongan fenolik, flavonoid, alkaloid, terpenoid-steroid, saponin dan tanin yang dapat memiliki bioaktivitas serta efek antijamur (Fitriana et al, 2014; Rita et al, 2013; Nanasombaat dan Teckchuen, 2009). Kandungan senyawa fenoliknya berupa flavonoid, asam galat, rutin, kuersetin, stibene, dan asam koumarik (Qader et al, 2012; Nkuete et al, 2015; Vikram et al, 2014). Senyawa flavonoid daun kesum adalah berupa kalkon, flavonon dan metil flavonol (Nkuete et al, 2015; Urones et al, 1990). Daun kesum diduga memiliki flavonoid yang sama dengan daun kesum spesies Thailand (Polygonum odoratum) meliputi rutin, katekin, kuarsetin, isohamnetin, dan kaempferol (Rita et al, 2013; Nanasombaat dan Teckchuen, 2009). Studi Johnny dkk menunjukkan ekstrak aseton $P$. minus memiliki aktivitas antijamur terhadap Colletotrichum capsici (Jonny et al, 2011).

Berdasarkan urainan di atas, penulis ingin melakukan penelitian mengenai aktivitas antijamur ekstrak etanol daun kesum (Polygonum minus Huds.) terhadap Microsporum canis.

\section{METODE PENELITIAN}

\section{A. Alat dan Bahan}

Alat yang digunakan pada penelitian ini adalah wadah kaca, lemari pendingin, sendok tanduk, bejana maserasi, rotary evaporator, timbangan analitik, sendok stainless, oven, inkubator, krusibel porselen, desikator, corong kaca, pinset, autoclave, gelas ukur, erlenmeyer, gelas beker, cawan penguap, tabung reaksi, batang pengaduk, cawan petri, kaca objek, kaca penutup, pipet tetes, pipet Pasteur, jangka sorong, jarum ose, mikroskop, kompor listrik, blender, dan pembakar Bunsen.
Bahan yang digunakan pada penelitian ini adalah dengan ekstrak etanol daun kesum (Polygonum minus Huds.) yang diujikan pada jamur Microsporum canis, aluminium foil, kertas saring, tissue, plastik tahan panas, kapas, karet, parafilm, kertas HVS, itrakonazol, akuades, etanol 96\%, spiritus, asam klorida $(\mathrm{HCl})$ pekat, eter, n-heksana-etil asetat, besi (III) klorida $\left(\mathrm{FeCl}_{3}\right)$, serium sulfat, larutan Liebermann-burchard, dragensorff, Agar Sabouraud Dekstrosa (ASD), DMSO, dan pewarna lactophenol cotton blue.

\section{B. Pengambilan dan Penyiapan Sampel}

Sampel berasal dari daun kesum (Polygonum minus Huds.) segar yang diperoleh dari Sungai Jawi (Pontianak). Pengambilan sampel tanaman dilakukan pagi hari. Tanaman daun kesum (Polygonum minus Huds.) yang telah dideterminasi, kemudian disortasi dari bahan-bahan pengotor. Kemudian daun kesum (Polygonum minus Huds.) dicuci dengan air mengalir hingga bersih dan dikeringkan hingga kering dengan cara dianginanginkan (selama \pm 2 minggu). Daun kesum (Polygonum minus Huds.) yang telah kering, dihaluskan dengan menggunakan blender hingga menjadi serbuk dengan ukurun derajat kehalusan serbuk simplisia yang sesuai. Serbuk simplisia yang ada disimpan dalam wadah kering tertutup rapat dalam ruangan terlindung dari cahaya matahari.

\section{Ekstraksi Sampel}

Serbuk simplisia daun kesum (Polygonum minus Huds.) sebanyak $500 \mathrm{mg}$ dimaserasi dengan menggunakan etanol $96 \%$ selama 72 jam dan pada tiap 12 jam sekali-kali dilakukan pengadukan. Hasil maserasi yang sudah direndam 24 jam disaring dengan dan selanjutnya residu kembali dimaserasi kembali selama 24 jam. Filtrat daun kesum (Polygonum minus Huds.) yang diperoleh, disatukan, dan dipekatkan dengan menggunakan rotary evaporator pada suhu $40^{\circ}-50^{\circ} \mathrm{C}$ hingga diperoleh ekstrak kental.

\section{Analisis Fitokimia}

Analisis fitokimia dalam penelitian ini menguji kandungan senyawa metabolit alkaloid, saponin, fenol, flavonoid dan terpenoid menggunakan metode uji tabung dan uji Kromatografi Lapis Tipis (KLT) (Marliana et al, 2005).

\section{E. Penyiapan Jamur Uji}

Isolat jamur Microsporum canis berasal dari Laboratorium Parasitologi Fakultas Kedokteran Universitas Indonesia. Identifikasi karakteristik jamur uji dilakukan secara makroskopis dan 
mikroskopis (Indrarjulianto et al, 2016; Meiliawati dan Kuswytasari, 2013). Pembuatan suspensi jamur dilakukan secara aseptis dengan cara uji pada media peremajaan yang berumur 24 jam diambil dengan menggunakan jarum ose dan disuspensikan ke dalam tabung berisi $5 \mathrm{~mL}$ akuades steril hingga homogen (Dalynn Biologicals, 2010).

\section{F. Uji Aktivitas Antijamur Ekstrak Daun Kesum terhadap Microsporum canis \\ Pengujian daya hambat ekstrak etanol daun}

kesum (Polygonum minus Huds.) terhadap pertumbuhan Microsporum canis dilakukan dengan metode difusi cakram berdiameter $5 \mathrm{~mm}$. Setelah inokulum sudah dioleskan pada permukaan media ASD, selanjutnya menempatkan kertas cakram yang telah diberikan sampel ekstrak, kontrol positif itrakonazol $8 \mu \mathrm{g} /$ disk, dan kontrol negatif akuades selama 15 menit pada permukaan lempeng ASD. Masing-masing kertas cakram sebanyak 4 buah diletakkan di atas media Agar Sabouraud Dekstrosa tersebut dengan jarak tiap cakram sebesar $4 \mathrm{~cm}$ dan dari tepi lempeng sebesar $2 \mathrm{~cm}$ terlihat pada Gambar 1 (Tortora et al, 2010; CLSI, 2012). Kemudian diinkubasi pada suhu $37^{\circ} \mathrm{C}$ selama $18-24$ jam.

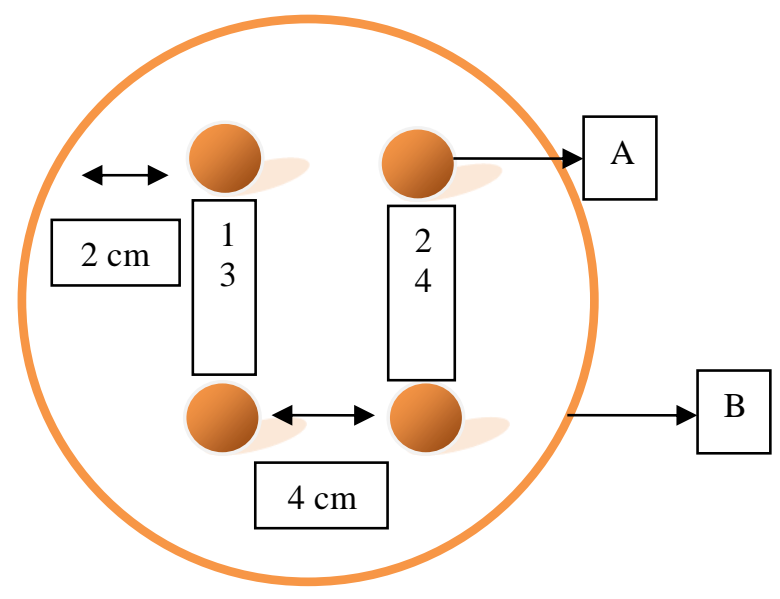

\author{
Keterangan: \\ A (1-4): Kertas cakram \\ B: Cawan petri
}

Gambar 1. Letak Cakram pada Media Uji Antifungi

Parameter yang diukur adalah zona hambat yang terbentuk pada tepi daerah kertas cakram (Tortora et al, 2010). Zona hambat tersebut diukur dengan jangka sorong. Setelah itu zona hambat yang terbentuk dibandingkan dengan diameter zona hambat kontrol positif. Adapun klasifikasi hambatan dapat dilihat pada Tabel 1.

Tabel 1. Klasifikasi Respon Hambatan Pertumbuhan Jamur (CLSI, 2012; Kandoli et al, 2016)

\begin{tabular}{cc}
\hline Diameter Zona Bening & Respon Hambatan Pertumbuhan \\
\hline $20 \mathrm{~mm}$ & Sangat Kuat \\
$11-20 \mathrm{~mm}$ & Kuat \\
$5-10 \mathrm{~mm}$ & Sedang \\
$0-4 \mathrm{~mm}$ & Lemah \\
\hline
\end{tabular}

\section{HASIL DAN PEMBAHASAN}

\section{Hasil Penelitian}

\section{Analisis Fitokimia}

Hasil analisis fitokimia pada penelitian menunjukkan ekstrak etanol daun kesum mengandung senyawa metabolit sekunder berupa golongan saponin, flavonoid, alkaloid, terpenoid dan fenol, dapat dilihat pada gambar 2 .

\section{Uji Aktivitas Antifungi}

Uji aktivitas antifungi pada penelitian ini menggunakan 5 variasi konsentrasi ekstrak etanol daun kesum yaitu 5\%, 10\%, 20\%, 40\%, dan $80 \%$.
Adanya aktivitas antifungi ditunjukkan dengan terbentuknya zona hambat di sekitar kertas cakram yang sebelumnya telah direndam dalam ekstrak etanol daun kesum selama 15 menit. Hasil uji aktivitas antifungi ekstrak etanol daun kesum terhadap Microsporum canis setelah diinkubasi selama empat belas hari pada suhu $37^{\circ} \mathrm{C}$ dengan variasi konsentrasi ekstrak etanol daun kesum 5\%, $10 \%, 20 \%, 40 \%$, dan $80 \%$ tidak menunjukkan adanya zona hambat, begitu pula dengan kontrol negatif. Sedangkan pada kontrol positif didapatkan zona 
hambat sebesar $50 \mathrm{~mm}$. Data dapat dilihat pada tabel

2 .

Tabel 2. Hasil Uji Aktivitas Antifungi Ekstrak Etanol Daun Kesum (Polygonum minus Huds.) terhadap Pertumbuhan Microsporum canis

\begin{tabular}{ccccccc}
\hline & & \multicolumn{3}{c}{ Diameter Zona Hambat (mm) } & \multirow{2}{*}{ Rata-rata (mm) } \\
\cline { 3 - 5 } No. & Konsentrasi & I & II & III & IV & \\
\hline 1. & $80 \%$ & 0 & 0 & 0 & 0 & 0 \\
2. & $40 \%$ & 0 & 0 & 0 & 0 & 0 \\
3. & $20 \%$ & 0 & 0 & 0 & 0 & 0 \\
4. & $10 \%$ & 0 & 0 & 0 & 0 & 0 \\
5. & $5 \%$ & 0 & 0 & 0 & 0 & 0 \\
6. & Kontrol (-) & 0 & 0 & 0 & 0 & 0 \\
7. & Kontrol (+) & 50 & 50 & 50 & 50 & 50 \\
\hline
\end{tabular}

Keterangan: $0=$ tidak terdapat zona hambat
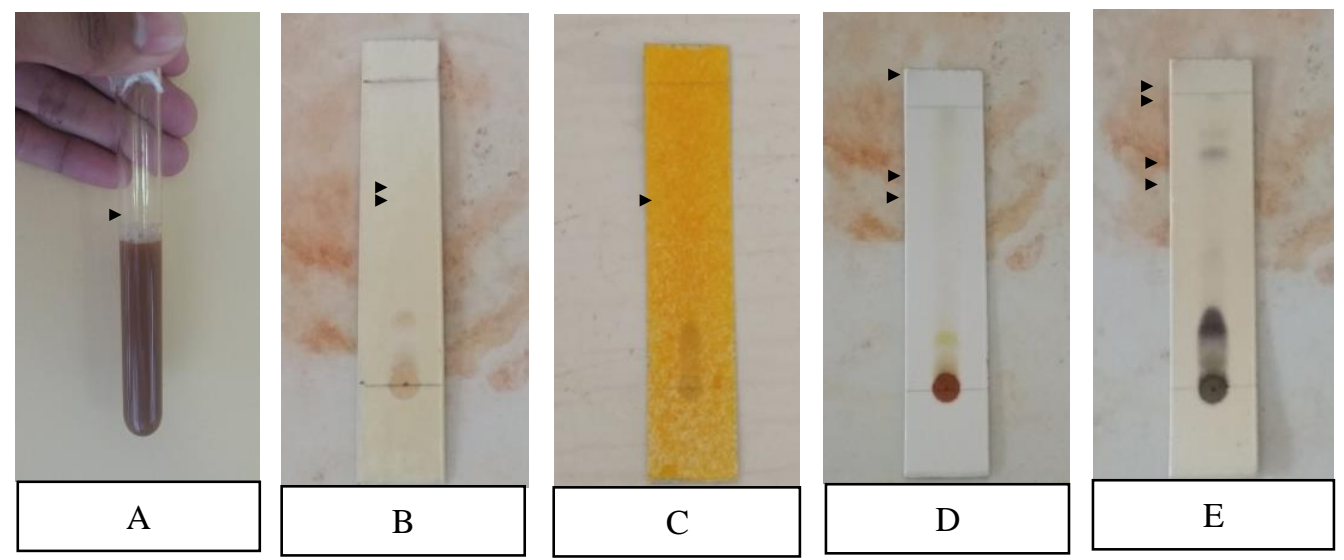

Gambar 2. Hasil Analisis Fitokimia Ekstrak Etanol Daun Kesum: (A) Saponin, (B) Flavonoid, (C) Alkaloid, (D) Terpenoid, dan (E) Fenol.

\section{Pembahasan}

Uji aktivitas antijamur ekstrak etanol daun kesum pada penelitian ini menggunakan metode difusi cakram Kirby-Bauer (Rex et al, 2009). Uji aktivitas antijamur ini bertujuan untuk mengetahui aktivitas antijamur ekstrak etanol daun kesum terhadap jamur Microsporum canis. Pada penelitian ini terdapat 5 kelompok perlakuan dengan variasi komponen ekstrak etanol daun kesum 80\%, 40\%, $20 \%, 10 \%$, dan $5 \%$ serta dua kontrol yaitu kontrol positif menggunakan itrakonazol $8 \mu \mathrm{g} /$ disk dan kontrol negatif menggunakan DMSO 10\%. Setelah inkubasi selama 14 hari dengan suhu $37^{\circ} \mathrm{C}$, kontrol positif menunjukkan adanya zona hambat di sekitar cakram sebesar $50 \mathrm{~mm}$. Pada kontrol negatif tidak menunjukkan adanya zona hambat yang terbentuk di sekitar kertas cakram. Uji aktivitas antijamur dengan menggunakan ekstrak etanol daun kesum dengan variasi konsentrasi $80 \%, 40 \%, 20 \%, 10 \%$, dan $5 \%$ didapatkan hasil tidak terbentuknya zona hambat di sekitar kertas cakram yang menunjukkan tidak adanya aktivitas antijamur terhadap jamur uji
Microsporum canis. Hasil negatif pada penelitian ini dapat dipengaruhi oleh berbagai faktor, seperti faktor jamur uji dan faktor obat.

Microsporum canis memiliki dinding sel tebal dan kasar serta fase pertumbuhan yang lambat (Shalaby et al, 2016; Soltys, 2015). Dinding sel jamur terdiri dari lapisan multipel (mannoprotein dan glukan $80 \%$, serta kitin 2\%). Mannoprotein secara predominan mengekspresikan permukaan eksternal. Susunan utama membran plasma jamur adalah ergosterol. Ergosterol memilki peran penting pada pertahanan sel jamur. Peran ergosterol adalah biosintesis, pengambilan dan pelepasan bahan, menghasilkan rangkaian karbohidrat, penyalur sinyal dari lingkungan, serta sebagai tempat penyimpanan enzim dinding sel. Faktor ini mempengaruhi seberapa efektif permeabilitas obat ke dalam sel jamur, semakin tebal dinding sel semakin sulit suatu senyawa masuk ke dalam sel (Nigam, 2015). Pertumbuhan Microsporum canis yang lambat juga berpengaruh pada pengobatan. Pertumbuhan lambat menunjukkan replikasi sel yang lambat atau adanyaa 
sel yang dorman, sehingga hal ini menyebabkan sel jamur tidak dapat dibunuh oleh zat antijamur (Cannon et al, 2009). Sedangkan jamur Trichophyton mentagrophytes memiliki dinding sel tipis dan fase pertumbuhannya sangat cepat, sehingga permeabilitas dan transport obat ke dalam sel jamur akan lebih mudah (Soltys, 1963).

Banyak obat antifungi yang memiliki target kerja pada ergosterol, yaitu pada ikatan dan sintesis ergosterol. Obat akan menyebabkan perubahan struktur pada membran lipid jamur sehingga obat akan lebih mudah dipenetrasi oleh sel jamur. Namun ergosterol memiliki mekanisme untuk pertahanan sel jamur. Ergosterol berfungsi sebagai bioregulator fluiditas membran dan integritas membran dalam sel jamur. Perubahan sterol dan/atau komposisi fosfolipid dari membran sel jamur dan fluiditas membran dapat berakibat pada penurunan penyerapan obat oleh sel jamur. Akumulasi obat secara intraseluler yang berkurang dapat juga terjadi karena peningkatan transpor aktif obat keluar dari sel (Nigam, 2015).

Selain faktor ketebalan dinding sel dan fase pertumbuhan, terdapat beberapa faktor lain yang dapat menyebabkan tidak efektifnya tanaman uji terhadap Microsporum canis; yaitu (1) enzim target diproduksi berlebihan, sehingga senyawa antijamur tidak dapat menghambat reaksi biokimia secara lengkap, (2) target senyawa antijamur diubah sehingga tidak dapat berikatan dengan target, (3) penetrasi senyawa antijamur dicegah masuk oleh membran sel atau dinding sel; (4) sel memiliki mekanisme untuk mengompensasi hilangnya fungsi karena aktivitas senyawa antijamur (Nigam, 2015).

Obat itrakonazol yang merupakan golongan triazol memiliki situs target yaitu biosintesis ergosterol (inhibisi Erg11p) dengan target sitokrom P450, 14 $\alpha$-Lanosterol, Demethylase (Nigam, 2015; Cannon et al, 2009). Pada penelitian ini itakonazol menunjukkan aktivitas antijamur yang baik terhadap Microsporum canis. Pada beberapa studi menunjukkan itrakonazol memiliki aktivitas antijamur yang baik terhadap Microsporum canis. Hal ini karena Microsporum canis masih sensitif terhadap itrakonazol dan belum mengalami resistensi terhadap itrakonazol.

Berdasarkan hasil uji aktivitas antijamur penelitian ini menunjukkan bahwa senyawa golongan saponin, flavonoid, alkaloid, terpenoid, dan fenol yang terdapat pada ekstrak etanol daun kesum tidak memiliki potensi sebagai antijamur terhadap Microsporum canis. Setiap senyawa yang terdapat di dalam tanaman memiliki aktivitas yang berbedabeda, walaupun merupakan senyawa satu golongan. Beberapa penelitian menyebutkan bahwa terpenoid merupakan senyawa utama yang berperan dalam aktivitas antijamur terhadap jamur dermatofita. Senyawa terpen yang utama dalam aktivitas antijamur terhadap dermatofita adalah monoterpenoid dan sesquiterpen (Trakranrungsie, 2011). Pada beberapa penelitian yang menguji aktivitas antijamur terhadap dermatofita, salah satu senyawa yang diduga berperan adalah flavonoid, yaitu isoflavon (Vila et al, 2013). Golongan alkaloid yang memiliki aktivitas antimikrob adalah cryptolepine. Namun pada penelitian ini senyawa golongan terpenoid, flavonoid, alkaloid, fenol dan saponin ekstrak etanol daun kesum tidak memiliki aktivitas antijamur. Setiap golongan senyawa memiliki jenis dan gugus yang berbeda, sehingga aktivitas yang dimiliki akan berbeda dan memiliki kekuatan aktivitas antimikrob yang berbeda (Kurniawan, 2015).

\section{KESIMPULAN}

Ekstrak etanol daun kesum (Polygounum minus Huds.) tidak memiliki aktivitas antifungi terhadap Microsporum canis sehingga konsentrasi efektif tidak dapat ditentukan.

\section{DAFTAR PUSTAKA}

Bertus N. V. P., H. E. J. Pandaleke, dan G. M. Kapantow. 2015. Profil Dermatofitosis di Poliklinik Kulit dan Kelamin RSUP Prof. Dr. R. D. Kandao Manado Periode JanuariDesember 2012. Jurnal e-Clinic 3(2): 7314.

Cannon R. D., E. Lamping, A. R. Holmes, K. Niimi, P. V. Baret, M. V. Keniya, K. Tanabe, M. dan Niimi, A. 2009. Goffeau, B. C. Monk. Efflux-mediated Antifungal Drug Resistance. Clinical Microbiology Reviews 22(2): 291-321.

Clinical and Laboratory Standards Institute. 2012. Performance Standards for Antimicrobial Testing: Twenty-second Informational Supplement. CLSI. USA.

Dalynn Biologicals. 2014. McFarland Standard. Dalynn Biologicals. Canada

Departemen Kesehatan Republik Indonesia. 2014. Farmakope Indonesia $V$. Departemen Kesehatan Republik Indonesia. Jakarta.

Fitriana N., Rumayati, N. Sumartini, A. Jayuska, Syaiful, dan Harliya. 2014. Formulasi Serbuk Flavour Makanan dari Minyak Atsiri Tanaman Kesum (Polygonum minus Huds) sebagai Penyedap Makanan. JATP 3(1): 125.

Johnny L., U. K. Yusuf, dan R. Nulit. 2011. Antifungal Activity Of Selected Plant Leaves Crude Extracts Against A Pepper Anthracnose Fungus, Colletotrichum 
capsici (Sydow) Butler And Bisby (Ascomycota: Phyllachorales). AJB 10(20): 4157-65.

Imelda F. 2013. Deteksi Senyawa Antibakteri Daun Kesum Secara KLT-Bioautografi dan Pengaruhnya terhadap Membran Escherichia coli dan Staphylococcus aureus. Tesis. Sekolah Pascasarjana Institut Pertanian Bogor. Bogor

Indrarjulianto S., Yanuartono, P. Hary, W. Puspa, dan Y. I. S. Gerson. 2016. Isolasi dan Identifikasi Microsporum canis dari Anjing Penderita Dermatofitosis di Yogjakarta. Jurnal Veteriner 15(2): 212-6.

Kandoli F., J. Abijulu, dan M. Leman. 2016. Uji Daya Hambat Ekstrak Daun Durian (Durio zybethinus) terhadap Pertumbuhan Candida albicans Secara In Vitro. Pharmacon Jurnal Ilmiah Farmasi 5(1): 46-52.

Kanti E. A. A. dan S. Rahmanisa. 2014. Tinea Corporiwith Grade Obesity In Women Domestic Workers Age 34 Years. Medula 2(4): 24-32.

Katzung B. G. 2015. Farmakologi Dasar dan Klinik. Edisi 13. Penerbit Buku Kedokteran EGC. Jakarta.

Kurniawan D. 2015. Uji Aktivitas Antijamur Ekstrak Etanol Daun Kelor (Moringa oleifera Lamk.) terhadap Candida albicans Secara In Vitro. Jurnal Mahasiswa PSPD FK Universitas Tanjungpura 3(1): [21p].

Maoz M. dan I. Neeman. 1998. Antimicrobial Effects Of Aqueous Plant Extracts On The Fungi Microsporum canis and Trichophyton rubrum and On Three Bacterial Species. Letters in Applied Microbiology 24: 61-3.

Marliana S. D., V. Suryanti, dan Suyono. 2005. Skrining Fitokimia dan Analisis Kromatografi Lapis Tipis Komponen Kimia Buah Labu Siam (Sechium edule Jacq. Swartz.) dalam Ekstrak Etanol. Biofarmasi 3(1):26-31.

Meiliawati D. dan N. D. 2013. Kuswytasari. Isolasi dan Identifikasi Jamur Kayu Lignolitik dari Vegetasi Mangrove Wonorejo. Jurnal Sains dan Seni Pomits 2(1): 16-19.

Michael, I. Kusharyanti, dan Isnindar. 2013. Pengaruh Ekstrak Metanol Daun Kesum (Polygonum minus Huds.) terhadap Peningkatan Kadar Kreatinin dan Ureum Serum Tikus Putih Galur Wistar Terinduksi Sisplatin. Jurnal Mahasiswa Farmasi Fakultas Kedokteran UNTAN 1(1): [9p].

Nanasombaat S. dan N. Teckchuen. 2009. Antimicrobial, Antioxidant and anticancer Activities Of Thai Local Vegetables.
Journal of Medicinal Plants Research 3(5): 443-9.

Nigam P. K.. 2015. Antifungal Drugs and Resistance: Current Concepts. Our Dermatol Online 2: 212-21.

Nkuete A. H. L., L. Migliolo, H. K. Wabo, P. Tane, dan O. L. Franco. 2015. Evaluation Of Multiple Functions Of Polygonum Genus Compounds. European Journal of Medicinal Plants 6(1): 1-16.

Qader S. W., M. A. Abdulla, L. S. Chua, H. M. Sirat, dan S. Hamdan. 2012. Pharmacological Mechanisms Underlying Gastroprotective Activities Of The Fractions Obtained from Polygonum minus in Sprague Dawley rats. Int J Mol Sci 13: 1481-1496.

Rex J. H., M. A. Ghannoum, B. D. Alexander, D. Andes, S. D. Brown, D. J. Diekema, A. Espinel-Ingroff, dan C. L. Fowler. 2009. Method for Antifungal Disk Diffusion Susceptibility Testing Of Yeasts Approved Guideline. Second edition. Clinical and Laboratory Standards Institute. USA.

Rita, I. Kusharyanti, dan S. Wahdaningsih. 2013. Uji Aktivitas Nefroprotektif Fraksi Metanol Danus Kesum (Polygonum minus Huds.) pada Tikus Jantan Galur Wistas (Rattus norvegicus) Yang Diinduksi Cisplatin. Jurnal Mahasiswa Farmasi Fakultas Kedokteran UNTAN 1(1): [10p].

Sari A. B., S. Widaty, K. Bramono, E. Miranda, dan M. Ganjardani. 2012. Laporan Kasus: Tinea Kapitis di Poliklinik Kulit Dan Kelamin RSUPN Dr Cipto Mangunkusumo Jakarta Periode Tahun 2005 - 2010. MDVI 39(3): 113-7.

Shalaby M. F. M., A. N. El-din, dan M. A. El-Hamd. 2016. Isolation, Identification, and In Vitro Antifungi Susceptibility Testing Of Dermatophytees From Clinical Samples At Sohag University Hospital in Egypt. Electronic Physician 8(6): 2557-67.

Siregar R. S. 2014. Atlas Berwarna Saripati Penyakit Kulit. Penerbit Buku Kedokteran EGC. Jakarta.

Soltys M. A. 1963. Bacteria and Fungi Pathogenic To Man and Animals. Bailliere Tindall and Cox. London.

Sutanto I., I. S. Ismid, P. K. Sjarifuddin, dan S. Sungkar. 2008. Buku Ajar: Parasitologi Kedokteran. Edisi Keempat. Balai Penerbit FKUI. Jakarta.

Syaiful A. J., A. Jayuska, dan Harlia. 2015. Pengaruh Waktu Distilasi terhadap Komponen Minyak Atsiri Pada Daun Kesum (Polygonum minus Huds.). JJK 4(1): 18-23. 
Tortora G. J., B. R. Funke, dan C. L. 2010. Case. Microbiology: an introduction. 10th edition. Pearson. US.

Trakranrungsie N. 2011. Plant Derived Antifungalstrends and Potential Applications In Veterinary Medicine: A Mini-Review. In: Science against microbial pathogens: communicating current research and technological advances. Ed. A. MendezVilas. Formatex Research Center 2: 11951204.

Urones J. G., I. S. Marcos, B. G. Perez, dan P. B. Barcala. 1999 Flavonoid from Polygonum minus. Phytochemistry 29(11): 3687-9.

Vena G. A., P. Chieco, F. Posa, A. Garotalo, A. Bosco, dan N. 2012. Cassano. Epidemiology Of Dermatophytoses: Retrospective Analysis From 2005-2010 And Comparison With Previous Data From 1975. New Microbiologica 35: 207-13.

Vikram P., K. K. Chiruvella, I. H. A. Ripain, dan M. Arifullah. 2014. A Recent Review On Phytochemical Constituents And Medicinal Properties Of Kesum (Polygonum minus Huds.). Asian Pac J Trop Biomed 4(6): 4305.

Vila R., B. Freixa, dan S. Canigueral. 2013. Antifungal Compounds From Plants. Recent Advances in Pharmaceutical Sciences III p23-43.

Wibowo M. A., M. A. Widodo, B. B. Purnomo, dan Aulianni'am. 2013. Ekstrak Daun Kesum (Polygonum minus) Melalui Ditekannya Produksi Reactive Oxygen Species (ROS). $J$ Ked Hewan 7(2): 160-2.

Widaty S. dan U. Budimulja. 2016. Dermatofitosis. Dalam Menaldi SL. Bramoko K, Indriati W. Ilmu Penyakit Kulit Dan Kelamin. Edisi Ketujuh. Badan Penerbit FKUI. Jakarta.

Yossela T. 2015. Diagnosis And Treatment Of Tinea Cruris. J Majority 4(2): 122-8. 